\title{
The use of isotretinoin in low doses and unconventional treatment regimens in different types of acne: a literature review
}

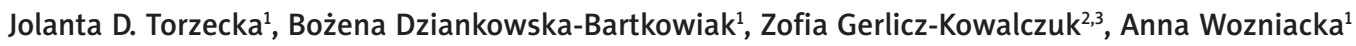

1Department of Dermatology and Venereology, Medical University of Lodz, Lodz, Poland

2Psychodermatology Department, Medical University of Lodz, Lodz, Poland

${ }^{3}$ Department of Dermatology, Pediatric Dermatology and Oncology, Medical University of Lodz, Lodz, Poland

Adv Dermatol Allergol 2017; XXXIV (1): 1-5

DOI: https://doi.org/10.5114/ada.2017.65614

\begin{abstract}
High effectiveness of isotretinoin treatment for severe types of acne resistant to antibiotics has been widely recognized. However, the recommended doses in conventional therapy, according to consensus of the Polish Dermatological Society, may cause serious adverse effects. Thus, research into less stressful, alternative treatment regimens with the use of low doses of isotretinoin has been carried out. The aim of the paper was to review the selected papers where authors present the results of their studies on different regimens with the use of isotretinoin in low doses in patients with acne, evaluate their efficacy, patient satisfaction, frequency of adverse effects, recurrences and also treatment costs.
\end{abstract}

Key words: acne vulgaris, isotretinoin, low doses, intermittent therapy.

Isotretinoin is a derivative of retinol (vitamin A). For treatment, it was introduced in the 1980-ties. Its efficacy was proved by dermatologists and documented in many papers [1-6]. Isotretinoin is indicated mainly for keloid acne, phlegmonous and fulminans acne, as well for severe papulopustular acne resistant to antibiotics [7-9]. The recommended daily dosage ranges from 0.5 to $1 \mathrm{mg}$ / $\mathrm{kg}$. The therapy should be continued for many months to reach the cumulative doses in total of $120-150 \mathrm{mg} / \mathrm{kg}$ [9]. The effective therapy is associated with subsidence of symptoms, prevention of scar development, strengthening of treatment results and minimizing the risk of recurrence $[1,10,11]$.

Isotretinoin may cause many adverse effects [12]; its teratogenic activity is the most serious, which means isotretinoin must not be taken during pregnancy. Effective contraception one month before, during and one month after the therapy is indicated [13]. The most common side effects include dry lips and cheilitis, blepharoconjunctivitis, rhinitis, erythema and dry facial skin, headaches, muscle and joint pains, and biochemical abnormalities such as increase in bilirubin, transaminase, triglycerides, decreased levels of high-density lipoprotein
(HDL) and increased low-density lipoprotein (LDL) cholesterol and uric acid [9, 12, 14, 15].

Occurrence of adverse effects, often serious and arduous, in the course of conventional treatment with isotretinoin led to the search for alternative treatment regimens, associated with the use of lower doses of the medicine.

In 1997, Goulden et al. [16] published the results of the study on 80 patients with acne (58 females and 22 males) treated with isotretinoin in the dose of $0.5 \mathrm{mg} /$ $\mathrm{kg} /$ day for 7 days followed by a 3-week interval. The therapy was continued for 6 months. In 75 individuals, who finished the therapy, a statistically significant $(p<0.0001)$ reduction in rash/eruption by Leeds scale was observed. The improvement was found in 68 (88\%) patients. Within 12-month observation period, recurrence was observed in 26 (39\%) subjects, mainly in those with lesions on the trunk. The authors concluded that the studied therapy was a cheaper, effective alternative to the traditional therapy with isotretinoin in a specifically selected group of patients, i.e. patients with dominant lesions on the face, the severity of changes $<1$ by Leeds scale, number of inflammatory changes $<20$ and worsening of sebum secretion $<1.25 \mu \mathrm{g} / \mathrm{cm}^{2} / \mathrm{min}$.

Address for correspondence: Jolanta D. Torzecka MD, PhD, Department of Dermatology and Venereology, Medical University of Lodz, pl. Hallera 1 build. 6, 90-647 Lodz, Poland, phone: +48 604437 151, e-mail: jolanta.torzecka@umed.lodz.pl Received: 21.12.2015, accepted: 26.02.2016. 
The effectiveness of an intermittent therapy was also confirmed by the results published by Kaymak et al. in 2006 [17]. In the study, 60 patients (34 females, 26 males, aged from 18 to 33 years) were given isotretinoin for 7 days followed by a 3-week interval. The therapy was continued for 6 months. The patients were divided into 3 groups according to the severity of skin lesions by Leeds scale; group I - moderate acne (1.25-1.5 by Leeds scale), the dosage of $0.75 \mathrm{mg} / \mathrm{kg} /$ day; group $\mathrm{II}$ - moderate acne (1 by Leeds scale), the dosage of $0.6 \mathrm{mg} / \mathrm{kg} / \mathrm{day}$; group III - mild acne ( 0.75 by Leeds scale), the dosage of $0.5 \mathrm{mg} / \mathrm{kg} /$ day. Forty one patients completed the therapy in groups I, II and III: 25/36, 10/16 and 6/9, respectively. Complete resolution of symptoms was observed in 34/41 patients (82.9\%) (19/25 in group I, 9/10 in group II and $6 / 6$ in group III). Partial improvement was observed in 6 patients from group I and 4 patients from group II. The most common side effects were: cheilitis observed in all patients, aggravation of acne (38/41), dry hands and eczema (7/41), muscle and joint pain (6/41). The increased level of triglycerides was present in 4/41 patients; similarly, the increased level of cholesterol was found in 4/41 patients; single individuals complained of anxiety (3/41), conjunctivitis (2/41), headaches and fatigue. Based on the obtained results, the authors conclude that intermittent therapy with isotretinoin is a safe and effective method of treatment in patients with moderate and mild acne.

Multicentre, randomized and controlled studies were carried out by Akman et al. in 2007. The authors compared intermittent and conventional isotretinoin therapies [18]. Sixty-six patients qualified for the study were divided into 3 groups: patients from group I were given isotretinoin at the dose of $0.5 \mathrm{mg} / \mathrm{kg} /$ day for 10 days each month, for 6 months; patients from group II received isotretinoin at the dose of $0.5 \mathrm{mg} / \mathrm{kg} /$ day for a month, then for 10 subsequent days each month for 5 months; in group III, isotretinoin at the dose of $0.5 \mathrm{mg} /$ $\mathrm{kg} /$ day was given every day for 6 months. After the treatment, the patients were observed for 12 months. Twentytwo patients from group I (19 females, 3 males, mean age: 22.7 years), 19 patients from group II (9 females, 10 males, mean age: 19.9 years) and 19 patients from group III (16 females, 3 males, mean age: 19.9 years) completed the study. Acne score after the therapy was statistically significantly lower $(p<0.001)$. When the obtained results were analyzed according to the acne severity: moderate acne -31 individuals, severe acne -29 , there were no statistically significant differences in the group of patients with moderate acne. However, the response to treatment in patients with severe acne was statistically significantly different in groups I and III ( $p=0.013)$, at the end of a 12-month observation period. Differences in the results between groups II and III were not statistically significant $(p=0.083)$. At the end of a 12 -month observation period, skin lesions were found in only $14 \%$ of the patients from group I. Both incidence and severity of adverse effects in groups I and II were lower than in group III.

Over the last 15 years, apart from papers on intermittent isotretinoin therapy, there have been papers on studies on patients given low doses of isotretinoin.

In 2003, Mandekou-Lefaki et al. [19] published the results of the studies on comparison between the use of conventional therapy and that with low doses in patients with different acne severity. The study group consisted of 64 patients (35 females, 29 males) divided into 2 groups. Thirty two subjects from group I received isotretinoin at the dose of $0.15-0.40 \mathrm{mg} / \mathrm{kg} /$ day, in group $1 \mathrm{-}-32$ subjects underwent conventional therapy with isotretinoin, at the dose of $0.5-1.0 \mathrm{mg} / \mathrm{kg} /$ day, up to cumulative dosage of $120 \mathrm{mg} / \mathrm{kg}$. Efficacy of the therapy was $69 \%$ in group I, $91 \%$ in group II and no recurrences were observed. The authors conclude that the therapy with low doses is effective, causes fewer adverse effects, has a beneficial effect on scars while the conventional therapy is more effective, protects from recurrences and scarring.

In 2006, Amichai et al. [20] presented the results of the prospective, cohort study, on 638 acne patients treated with isotretinoin at the dose of $20 \mathrm{mg} /$ day $(0.3-$ $0.4 \mathrm{mg} / \mathrm{kg} /$ day), for 6 months. The patients were divided into 2 groups according to age: group I - patients aged between 12 and 20 years, and group 11 - patients aged from 21 to 35 years. Twenty two patients out of 638 stopped the treatment. Improvement in skin lesions was observed, in group I in 94.8\%, in group II - in $92.6 \%$ of the patients. Within a 4-year observation period, recurrence was found in $3.9 \%$ of the patients from group I and $5.9 \%$ from group II. Deviation from the norm was found in the results of additional tests: increased lipid level (> 20\%) in $4.2 \%$ and elevated liver tests (2-fold increase) were seen in $4.8 \%$ of the patients. Based on the obtained results, the authors conclude that 6 -month therapy with low doses of isotretinoin is effective in moderate acne, adverse effects are rarely observed and the cost of treatment is lower than with the use of the conventional method.

A similar therapeutic regimen was used by Sardana et al. [21]; isotretinoin at the dose of $20 \mathrm{mg} /$ day (i.e. about $0.15-0.28 \mathrm{mg} / \mathrm{kg} /$ day) combined with local application of $1 \%$ clindamycin gel was administered every second day, for 6 months. Prospective studies were carried out on 320 patients diagnosed with moderately severe acne. The study was followed by a 6-month observation period. The study was completed by 305 patients. The average cumulative dose taken by patients was 38.4 $\mathrm{mg} / \mathrm{kg}$. A very good effect of the therapy was observed in $208 / 305$ patients (68.2\%), good in 59/305 patients (19.34\%), while no improvement was found in 38/305 patients (12.46\%). Within a 6-month observation period, recurrences occurred in 50 (16.39\%) patients, mostly in women diagnosed with polycystic ovary syndrome 
(37/43). The adverse effects were: mild cheilitis (91\%) and xerosis (43\%), deviations in lab tests included: elevated levels of liver enzymes (5\%) and serum lipids (6\%).

In 2011, Lee et al. [22] published the results of randomized, controlled studies aimed at the comparison of conventional therapy with isotretinoin, vs. therapy with low doses, vs. intermittent therapy. Sixty patients with moderate acne were qualified for the study. The subjects were divided into 3 groups; patients in group A were given isotretinoin at the dose of $0.5-0.7 \mathrm{mg} / \mathrm{kg} /$ day for 24 weeks, in group B - isotretinoin at the dose of $0.25-0.4 \mathrm{mg} / \mathrm{kg} /$ day also for 24 weeks, in group C isotretinoin dosed $0.5-0.7 \mathrm{mg} / \mathrm{kg} /$ day for 7 days followed by a 3-week interval, for 6 months. Efficacy, tolerability of the therapy and patient satisfaction were compared in all groups. The therapy was followed by 1 year of observation. Evaluation by GAGS (Global Acne Grading System) showed statistically significant differences between groups $A$ and $C$ as well as $B$ and $C$. The number of both inflammatory and non-inflammatory lesions was statistically significantly different in groups B and C as well as $C$ and $A$ whereas there were no statistically significant differences between groups $A$ and $B$, which suggests that conventional therapy and therapy with low doses of isotretinoin are similarly effective. Patient satisfaction scores were the highest in group B (low doses of the drug), lower in group C (intermittent therapy) and the lowest in group A (conventional therapy). Adverse effects occurred most commonly in patients treated with the use of conventional method (group A), compared to the groups treated with low doses of isotretinoin (group B) and intermittent method (group C). Within a one-year observation period, recurrences were present in 2/16 patients in group A, 3/17 in group B and 9/16 in group $C$. In conclusion, the authors highlight that considering tolerability, efficacy and patient satisfaction, the therapy with low doses of isotretinoin is most recommended for patients with moderate acne.

In 2014, Rasi et al. [23] prolonged the period of treatment with isotretinoin dosed $20 \mathrm{mg} /$ day. Administration of the drug was continued until a cumulative dose of $120 \mathrm{mg} / \mathrm{kg}$ was reached. The retrospective study was done on 140 patients (89 females, 51 males) aged 18-40 years (mean: 23.78) diagnosed with moderate and severe acne with tendency toward scarring. The patient weight ranged from 50 to $110 \mathrm{~kg}$ (mean: $65.89 \mathrm{~kg}$ ). Total clearance was achieved in 135 out of 140 patients treated with the use of this method (96.4\%). The longest time of the therapy was 22 months, the shortest -10 months. Within a 5-year observation period, recurrences were found in $11(7.9 \%)$ individuals; $5.9 \%$ of males and $8.9 \%$ of females. Mean time from treatment completion to a relapse was 17.27 months. Adverse effects during the therapy were mild and included: cheilitis (66.4\%), xerosis (8.5\%), arthralgia (4.2\%), and epistaxis (2.8\%). Slightly elevated levels of liver enzymes and lipids in serum were found in 20 subjects.

Kotori [24] treated his patients with isotretinoin dosed $20 \mathrm{mg} / \mathrm{kg}$ (about 0.3-0.4 mg/kg/day) for only 3 months. The study was done on 50 patients ( 25 females, 25 males); a half of the group received the above treatment regimen while the other half was given isotretinoin locally only. The patients were divided into 2 age groups: group I consisted of patients aged 12-20 years while group $\|$ - those aged 21-35 years. After a 3-month therapy, an improvement was observed in $90.8 \%$ (group I), in group $\|-89.6 \%$ of the patients. Four patients did not complete the therapy. Within a 2-year observation period after the treatment, recurrences occurred in 3.9\% of the patients in group I and 5.9\% from group II. Adverse effects: elevated lipid levels (> 20\% of the norm) were found in $4.2 \%$, a 2 -fold increase in liver function tests in $4.8 \%$ of the patients. The author concludes that a 3-month therapy with isotretinoin dosed $20 \mathrm{mg} /$ day in patients with moderate acne is safe, carries a low risk of developing adverse effects, and the cost of the therapy is lower compared to the conventional therapy.

Rademaker et al. [25] proposed a special kind of isotretinoin therapy to his adult patients with chronic acne. A randomized study with double-blind trial was carried out on 60 patients, aged 25-55 years. The patients were divided into 2 groups: in group I, the patients were administered isotretinoin of $5 \mathrm{mg}$ /day for 32 weeks, in group II, the patients were given placebo for the first 16 weeks followed by an open-label study where isotretinoin dosed $5 \mathrm{mg} /$ day was given for the subsequent 16 weeks. All patients underwent a check-up 10 weeks after completing the therapy (45 patients finished the study). There were statistically significant differences $(p<0.0001)$ in the number of skin lesions, quality of life indicators (Dermatology Life Quality Index - DLQI) in patients after 16 weeks of taking isotretinoin compared to the patients receiving placebo.

The fastest significant reduction in skin lesions was observed within the first 4 weeks of the treatment (group I). A systematic though less dynamic improvement was seen until the $32^{\text {nd }}$ week of the therapy (mean number of skin lesions before the therapy - 11.3, in week $16-3.6$, in week $32-1.3$; $p<0.0001$ ). A similar, statistically significant reduction in skin lesions was found in group II, however, only in week 20, i.e. 4 weeks after administration of isotretinoin. There was a total clearance of the lesions in $62 \%, 1$ acne eruption in $21 \%$ of the patients. During the therapy, adverse effects were minor and included episodes of dry skin and/or nasal dryness/dry mouth.

Isotretinoin (13-cis-retinoic acid), a first-generation retinoid, influences the basic pathogenic factors for acne: suppresses sebum production, demonstrates comedolytic activity, has direct and indirect anti-inflammatory activity, despite having no antibacterial properties, significantly reduces Propionibacterium acnes population. 
Table 1. Treatment modalities

\begin{tabular}{|c|c|c|c|}
\hline Author & $\begin{array}{l}\text { Number } \\
\text { of patients }\end{array}$ & Treatment modality & $\begin{array}{l}\text { Treatment } \\
\text { duration }\end{array}$ \\
\hline Goulden et al. (1997) [16] & 80 & Isotretinoin $0.5 \mathrm{mg} / \mathrm{kg} /$ day during 7 days and 3-week break & 6 months \\
\hline Kaymak et al. (2006) [17] & 60 & $\begin{array}{l}\text { Isotretinoin } 0.75 \mathrm{mg} / \mathrm{kg} / \text { day during } 7 \text { days } \\
\text { and 3-week break } \\
\text { Isotretinoin } 0.6 \mathrm{mg} / \mathrm{kg} / \text { day during } 7 \text { days and 3-week break } \\
\text { Isotretinoin } 0.5 \mathrm{mg} / \mathrm{kg} / \text { day during } 7 \text { days and 3-week break }\end{array}$ & 6 months \\
\hline $\begin{array}{l}\text { Akman et al. (2007) [18] } \\
\text { randomized, controlled, } \\
\text { multicenter study }\end{array}$ & 66 & $\begin{array}{l}\text { Isotretinoin } 0.5 \mathrm{mg} / \mathrm{kg} / \text { day during } 10 \text { days of each month } \\
\text { Isotretinoin } 0.5 \mathrm{mg} / \mathrm{kg} / \text { day each day in the first month } \\
\text { and } 10 \text { days of each month for } 5 \text { months } \\
\text { Isotretinoin } 0.5 \mathrm{mg} / \mathrm{kg} / \text { day every day }\end{array}$ & 6 months \\
\hline $\begin{array}{l}\text { Mandekou-Lefaki et al. } \\
\text { (2003) [19] }\end{array}$ & 64 & $\begin{array}{l}\text { Isotretinoin } 0.15-0.40 \mathrm{mg} / \mathrm{kg} / \mathrm{day} \\
\text { Isotretinoin } 0.5-1.0 \mathrm{mg} / \mathrm{kg} / \mathrm{day}\end{array}$ & $\begin{array}{l}\text { Total dose up to } \\
120 \mathrm{mg} / \mathrm{kg}\end{array}$ \\
\hline Amichai et al. (2006) [20] & 638 & Isotretinoin 20 mg/day (0.3-0.4 mg/kg/day) & 6 months \\
\hline Sardana et al. (2009) [21] & 320 & $\begin{array}{l}\text { Isotretinoin } 20 \mathrm{mg} / \text { day every other day } \\
(0.15-0.28 \mathrm{mg} / \mathrm{kg} / \text { day })\end{array}$ & 6 months \\
\hline $\begin{array}{l}\text { Lee et al. (2011) [22] } \\
\text { randomized, controlled study }\end{array}$ & 60 & $\begin{array}{c}\text { Isotretinoin } 0.5-0.7 \mathrm{mg} / \mathrm{kg} / \text { day } \\
\text { Isotretinoin } 0.25-0.4 \mathrm{mg} / \mathrm{kg} / \text { day } \\
\text { Isotretinoin } 0.5-0.7 \mathrm{mg} / \mathrm{kg} / \text { day during } 7 \text { days and 3-week break }\end{array}$ & 6 months \\
\hline Rasi et al. (2014) [23] & 140 & Isotretinoin 20 mg/day & $\begin{array}{l}\text { Up to cumulative } \\
\text { dose of } 120 \mathrm{mg} / \mathrm{kg}\end{array}$ \\
\hline Kotori (2015) [24] & 50 & Isotretinoin 20 mg/day & 3 months \\
\hline $\begin{array}{l}\text { Rademaker et al. (2014) [25] } \\
\text { randomized, double-blind, } \\
\text { placebo-controlled study }\end{array}$ & 60 & Isotretinoin $5 \mathrm{mg} /$ day & 16 weeks \\
\hline
\end{tabular}

Isotretinoin effect on metalloproteinases (MMP) and tissue inhibitors of MMP (TIMP) contribute to matrix degradation, preventing scarring [9].

The use of isotretinoin in Member States of the European Union, regulated by the Directive of the European Medicine Agency (EMA), is approved for severe forms of acne, such as nodular or conglobate acne or acne at risk of scarring. However, many groups of recognized experts, including the team appointed by the Polish Dermatological Society to develop consensus treatment for acne, recommend isotretinoin therapy also to patients with less severe acne [9]. Our results in this group of patients confirm the efficacy of small doses in intermittent therapy: isotretinoin of 20/mg for 7 days followed by a 2-week break (the results were presented at the $2^{\text {nd }}$ Scientific and Training Conference of Association of Military Dermatologists in May 2012). The undeniable advantages of the intermittent therapy include: very good tolerability, easy management, and low cost. Improvement of the lesions is slower, the therapy is not accompanied by bothersome side effects, however, the therapy may run an increased risk of recurrence compared with the conventional treatment. A reduction in sebum production, cheilitis reported by most patients confirm activity of even low doses of isotretinoin. Drug accumulation (the concentration of retinoid returns to the physiological level after 2 weeks) explains the improvement of the lesions despite interruptions in the application of the drug. Our results suggest that the proposed intermittent low-dose therapy with isotretinoin is preferred by the patients, which is proved by patients with recurrences being willing to repeat the therapy.

Although high doses of isotretinoin are recognized as a standard treatment, on the other hand, a number of clinical studies indicate that in most patients with a moderate form of acne, lower dosage of the drug is sufficient to achieve improvement and what is most important is safer because of significantly fewer side effects. Encouraging results of the authors of the cited publications extend the therapeutic approach to acne and can be widely used in the daily dermatological practice (Table 1).

\section{Acknowledgments}

This work was supported by grant from the Medical University of Lodz no. 503/1-152-01/503-11-002.

\section{Conflict of interest}

The authors declare no conflict of interest. 


\section{References}

1. Layton AM, Knaggs HE, Taylor J, Cunliffe WJ. Isotretinoin for acne vulgaris -10 years later. A save and successful treatment. Br J Dermatol 1993; 129: 292-6.

2. Cunliffe WJ, van de Kerhof PC, Caputo R, et al. Roaccutane treatment guidelines: result of an international survey. Dermatology 1997; 194: 351-7.

3. Layton AM, Dreno B, Gollnick HP, Zouboulis CC. A review of the European Directive for prescribing systemic isotretinoin for acne vulgaris. J Eur Acad Dermatol Venereol 2006; 20: 773-6.

4. Layton AM. The use of isotretinoin in acne. Dermatoendocrinology 2009; 1: 162-9.

5. Kaszuba A, Kisiel K, Uczniak S. Izotretinoina doustna w leczeniu różnych odmian klinicznych trądziku pospolitego. Forum Med Rodz 2009; 3: 257-65.

6. Matusiak $Ł$, Szepietowski J. Izotretinoina w trądziku - schematy dawkowania w aspekcie skuteczności, interakcji, tolerancji, bezpieczeństwa oraz kosztów terapii. Dermatol Klin 2011; 13: 145-54.

7. Ross JI, Snelling AM, Carnegie E, et al. Antibiotic-resistant acne: lessons from Europe. Br J Dermatol 2003; 148: 467-78.

8. Ross JI, Snelling AM, Carnegie E, et al. Antibiotic-resistant of acne vulgaris. J Dermatolog Treat 2006; 17: 217-21.

9. Szepietowski J, Kapińska-Mrowiecka M, Kaszuba A, et al. Trądzik zwyczajny: patogeneza i leczenie. Konsensus Polskiego Towarzystwa Dermatologicznego. Przegl Dermatol 2012; 99: 649-73.

10. Azoulay L, Oraichi D, Berard A. Isotretinoin therapy and the incidence of acne relapse: a nested case-control study. $\mathrm{Br}$ J Dermatol 2007; 157: 1240-8.

11. Rademaker M. Isotretinoin dose, duration and relapse. What does 30 years of usage tell us? Australas I Dermatol 2013; 54: 157-62.

12. Rademaker M. Adverse effects of isotretinoin: a retrospective review of 1743 patients started on isotretinoin. Australas J Dermatol 2010; 51: 248-53.

13. Berard A, Azoulay L, Koren G, et al. Isotretinoin, pregnancies, abortions and birth defects: a population-based perspective. Br J Pharm 2007; 63: 196-205.

14. Zane LT, Leyden WA, Marqueling AL, Manos MM. A population-based analysis of laboratory abnormalities during isotretinoin therapy for acne vulgaris. Arch Dermatol 2006; 142: 1016-22.

15. Cemil BC, Ayvaz HH, Ozturk G, et al. Effects of isotretinoin on body mass index, serum adiponectin, leptin, and ghrelin levels in acne vulgaris patients. Adv Dermatol Allergol 2016; 33: 294-9.

16. Goulden V, Clark SM, McGeown C, Cunliffe WJ. Treatment of acne with intermittent isotretinoin. Br J Dermatol 1997; 137: 106-8.

17. Kaymak Y, Ilter N. The effectiveness of intermittent isotretinoin treatment in mild or moderate acne. J Eur Acad Dermatol Venereol 2006; 20: 1256-60.

18. Akman A, Durusoy C, Senturk M, et al. Treatment of acne with intermittent and conventional isotretinoin: a randomized, controlled multicenter study. Arch Dermatol Res 2007; 299: 467-73.

19. Mandekou-Lefaki I, Delli F, Teknetzis A, et al. Low-dose schema of isotretinoin in acne vulgaris. Int J Clin Pharmacol Res 2003; 23: 41-6.

20. Amichai B, Shemer A, Grunwald MH. Low-dose isotretinoin in the treatment of acne vulgaris. J Am Acad Dermatol 2006; 54: 644-6.
21. Sardana K, Garg VK, Sehgal VN, et al. Efficacy of fixed low-dose isotretinoin (20 mg, alternate days) with topical clindamycin gel in moderately severe acne vulgaris. J Eur Acad Dermatol Venereol 2009; 23: 556-60.

22. Lee JW, Yoo KH, Park KY, et al. Effectivenes of conventional, low-dose and intermittent oral isotretinoin in the treatment of acne: a randomized, controlled comparative study. $\mathrm{Br}$ J Dermatol 2011; 164: 1369-75.

23. Rasi A, Behrangi E, Rohaninasab M, Nahad ZM. Efficacy of fixed daily $20 \mathrm{mg}$ of isotretinoin in moderate to severe scar prone acne. Adv Biomed Res 2014; 3: 103.

24. Kotori MG. Low-dose vitamin "A" tablets - treatment of acne vulgaris. Med Arch 2015; 69: 28-30.

25. Rademaker M, Wishart JM, Birchall NM. Isotretinoin 5 mg daily for low-grade adult acne - a placebo-controlled, randomized double-blind study. JEADV 2014; 28: 747-54. 